\title{
Impact of Whole Blood Storage Conditions in Flow Cytometric Analysis for Paroxysmal Nocturnal Hemoglobinuria
}

\author{
Sewon Yoon ${ }^{\circledR}$, Jimyung Kim ${ }^{\circledR}$, Seon Young Kim ${ }^{\circledR}$, Jinsook Lim ${ }^{\circledR}$, Gye Cheol Kwon ${ }^{\circledR}$, and Sun Hoe Koo \\ Department of Laboratory Medicine, Chungnam National University Hospital, Daejeon, Korea
}

\section{Corresponding author:}

Jimyung Kim

Department of Laboratory Medicine, Chungnam National University Hospital, 282 Munhwa-ro, Jung-gu, Daejeon 35015, Korea

Tel +82-42-280-7998

E-mailjmkim@cnuh.co.kr

Received: February 10, 2021

Revised: April 12, 2021

Accepted: April 26, 2021
This is an Open Access article distributed under the terms of the Creative Commons Attribution Non-Commercial License (http://creativecommons.org/licenses/ by-nc/4.0) which permits unrestricted non-commercial use, distribution, and reproduction in any medium, provided the original work is properly cited.
Background: We evaluated the effect of four blood storage conditions (refrigeration, fixation [with the Cyto-Chex and TransFix tubes], and physiologic stabilization using Ficoll polymer PM70) for 72 hours in flow cytometric analysis of paroxysmal nocturnal hemoglobinuria (PNH).

Methods: Peripheral whole blood (WB) was collected in Cyto-Chex tubes (Streck, USA), TransFix tubes (Cytomark, UK) and ethylenediaminetetraacetic acid (EDTA) tubes (Becton Dickinson, USA) from 20 patients with a PNH clone $(\geq 1.0 \%)$ and 15 controls. PM70 (10\%; GE Healthcare, USA)-EDTA WB was prepared. Samples were stored at room temperature (RT) or $4^{\circ} \mathrm{C}$ for 72 hours. Flow cytometric analysis was performed within 4 hours and 72 hours.

Results: The percentage of PNH clones was stable in stored WB at RT without systemic error, except for those stored in EDTA WB. A substantial correlation was observed between the fresh WB and stored WB. The mean fluorescence intensity of CD235a in red blood cells (RBCs) and CD15 in neutrophils decreased in stored WB, while CD59, CD24, and fluorescent aerolysin of the PNH clone showed no significant difference. The percentage of CD15 (+) neutrophils was not different between the fresh WB and stored WB. However, the viability of granulocytes was more than $90 \%$ in the refrigerated EDTA WB. Conclusions: Stable measurement of PNH clones in RBCs and neutrophils is possible in refrigerated the EDTA WB for up to 72 hours. In the case of storage at RT, physiological stabilization using 10\% PM70 can be an alternative method for WB fixation.

(Lab Med Qual Assur 2021;43:143-151)

Key Words Paroxysmal hemoglobinuria, Flow cytometry, Stabilization, Fluorescence

\section{서론}

발작성야간혈색뇨증(paraoxysmal nocturnal hemoglobinuria, $\mathrm{PNH}$ )은 phosphatidylinositol glycan class $\mathrm{A}$ (PIGA) 유전자의 돌연변이로 인한 드문 혈액질환으로 적혈구의 CD59 및 백혈구의 fluorescein-labeled proaerolysin (FLAER) 발현을 측정하는 유세포 분석법이 $\mathrm{PNH}$ 를 진단하는 표준방법이다
[1]. 유세포 분석 검사는 혈액 검체를 이용하여 적혈구 및 백혈구 세포에서 발현되는 보체활성 억제 단백을 분석하므로 채혈 후 혈 구세포의 안정성이 유지되는 시간 내에 검사가 이루어져야 정확 한 결과를 도출할 수 있다. 분석 허용시간에 대한 International Clinical Cytometry Society (ICCS) 가이드라인에 의하면 적혈 구 분석은 검체를 냉장 온도에서 보관할 경우 최대 7 일까지 성공 적으로 수행될 수 있다. 그러나 백혈구는 적혈구에 비해 체외 안정 
성이 취약하므로 백혈구 분석은 48시간 이내 수행하도록 제시한 다[2]. 검체 보관기간에 대한 연구가 제한적이므로 대부분의 국내 임상검사실에서 PNH 진단을 위한 유세포 분석 검사는 일반적으 로 당일에 시행되며, 당일 시행이 어려운 경우는 ICCS 가이드라인 을 근거하여 냉장보관 조건을 기준으로 48 시간 이내 검사되도록 허용한다.

$\mathrm{PNH}$ 진단을 위한 유세포 분석 검사가 48시간까지 검사 시행의 연장이 허용되지만, 금요일이나 연휴 전일 오후에 늦게 검사실로 접수되는 검체의 경우 접수일에 검사가 수행되지 않는다면 유세포 분석 검사는 48 시간 경과 후 시행되게 된다. 특히 유세포 분석 검 사를 자체 수행하지 않고 외부기관으로 의뢰하는 임상검사실은 검 체 수송과정을 고려하면 냉장보관 및 48시간 기준을 충족하기 어 려운 경우가 자체 수행 검사실보다 높은 빈도로 발생할 수 있다. 또한 유세포 분석 검사실은 일반적으로 단수의 장비를 운용하며, 임상검사실 내 운용 경험을 가진 검사자의 수가 적어 장비나 인력 운용의 문제 발생 시 신속하게 대체하는 것이 어려워 48시간 규정 을 초과하는 상황도 가능하다.

그러므로 기존의 기준인 냉장, 48 시간 검사 가능 조건을 극복하 는 방안이 필요하나 현재 시간 및 온도에 따른 PNH 세포의 안정 성에 관한 연구는 적으며, 한 국내 연구는 검체를 냉장보관하면 호 중구 분석 시 PNH 클론의 크기가 72 시간까지 안정되게 측정된다 고 보고하였으나 분석 검체의 수가 적었다[3].

유세포 분석이 지연되고 실온에서 검체가 운송되는 경우 유핵 세포의 세포표지자를 안정화시키고 세포 변성을 막는 최적의 방법 은 TransFix나 Cyto-Chex 등의 상품화된 채혈관을 사용하는 것 이며, 이러한 채혈관은 보고에 의하면 실온에서 72 시간까지 백혈 구 세포의 세포표지자 발현과 세포 구분이 안정되게 유지되었으며 림프구 수는 7일까지 유의한 변화가 없었다[4,5]. 그러나 별도의 특수 채혈관은 임상검사실에 적용할 경우 추가적인 소모품 비용의 상승을 초래한다. 또한 특수한 채혈관의 사용은 검체 채취과정에 서 혼란이 초래될 수 있어 유세포 분석에 도입하는 것이 용이하지 않다.

최근 TransFix나 Cyto-Chex 등의 세포 안정화 시약 외에 혈액 의 보관 중 발생하는 세포의 물리학적인 변화를 억제하여 세포의 체외 생존도를 향상시키는 방법이 소개되었다. 이는 세포의 활성 화가 혈소판의 응집 및 백혈구의 변성을 초래한다는 것에 기초한 것으로 질량이 작은 중합체(polymer)를 첨가하여 혈구세포의 유 동학적 특성(rheological property)을 조정함으로써 혈구세포의 침강(sedimentation)을 억제하고 세포 생존도를 향상시키는 것 이다[6,7].

실제로 조혈모세포의 세포 군집 형성(colony formation) 연구 에서 일반적으로 사용되는 중합체인 메틸셀룰로오스를 바탕으로
하는 배지는 조혈모세포가 배지에서 서로 뭉치지 않고 분리되도록 한다[8]. 또한 중성 전하와 고도의 친수성으로 생체적으로 적합한 다당류 Ficoll을 이용한 연구에서 Ficoll 중합체는 실온에서 72시 간 동안 혈액세포를 안정하게 보존하는 것으로 보고되었다[6]. 별 도의 특수 채혈관에 비해 Ficoll 중합체는 필요한 경우 채혈된 검 체에 추가적으로 가하게 되므로 임상검사실에서 필요에 따라 적용 하는 것이 용이하며 비용이 절감되는 장점이 있다.

본 연구의 목적은 국내 임상검사실의 실정을 고려하여 $\mathrm{PNH}$ 환 자군 및 비환자군에서 별도의 채혈관에 채혈하는 방법과 Ficoll 중 합체를 ethylenediaminetetraacetic acid (EDTA) 전혈에 첨가 하는 방법이 시간 경과에 따라 검사결과에 미치는 영향을 비교하 고자 한다. 이를 통해 유세포 분석법에서 분석의 안정성을 72 시간 이상 확보할 수 있는 첨가제로써 Ficoll 중합체의 적용이 적절한지 검토하고자 한다.

\section{재료 및 방법}

\section{1. 검체 준비}

2019년 5월부터 11월까지 PNH 유세포 분석 검사가 의뢰되고 적혈구 혹은 호중구에서 $1 \%$ 이상의 의미 있는 $\mathrm{PNH}$ 클론을 가지 는 환자군 20명(50.9 \pm 19.1 세, 남:녀=10:10)과 의미 있는 $\mathrm{PNH}$ 클론을 가지지 않는 비환자군 15 명(52.7 \pm 19.0 세, 남:녀=7:8)에 서 EDTA 채혈관(Becton Dickinson, Franklin Lakes, NJ, USA), Cyto-Chex 채혈관(Streck, La Vista, NE, USA), TransFix 채혈 관(Cytomark, Buckingham, $\mathrm{UK}$ )에 각각 $3 \mathrm{~mL}, 5 \mathrm{~mL}, 3 \mathrm{~mL}$ 의 전혈을 채혈하였다.

EDTA 전혈에 첨가제로 사용할 Ficoll 중합체 용액의 제조하기 위해 우선 phenol red를 포함하지 않는 RPMI 1640 Medium (Thermo Fisher Scientific, Carlsbad, CA, USA)에 최종 농도 $10 \mathrm{mM}$ 로 HEPES (Thermo Fisher Scientific)를 가한 후 여과 를 거쳐 무균액을 준비하였다. 준비된 무균액에 Ficoll PM70 (GE Healthcare, Chicago, IL, USA)을 녹여 20\% Ficoll PM70 stock solution을 제조하였다. EDTA 전혈과 20\% Ficoll PM70 stock solution을 1:1의 비율로 섞고 10-15분간 충분히 혼합하여 $10 \%$ Ficoll PM70을 포함하는 EDTA 전혈 검체를 준비하였다[6].

이전 보고에서 상품화된 채혈관은 실온 조건에서 안정성이 평 가되었으므로[4,5], 준비된 3종의 검체(10\% PM70 전혈, CytoChex 전혈, TransFix 전혈)는 실온, 72 시간 보관 조건에, EDTA 전혈 검체는 2 개로 분주하여 각각 실온과 냉장 온도에서 72 시간 보관 조건에 두고 안정성을 평가하였다. 


\section{2. 적혈구 및 호중구의 PNH 유세포 분석}

통상적인 PNH 유세포 분석 검사는 채취된 EDTA 전혈 검체에 대해 채혈 후 4시간 이내에 시행되었다[9]. 또한 채혈 후 72 시간이 경과된 시점에 4종의 검체(EDTA 전혈, $10 \%$ PM70 전혈, CytoChex 전혈, TransFix 전혈)를 대상으로 PNH 유세포 분석 검사를 시행하였다.

적혈구에서 $\mathrm{CD} 59$ 의 발현을 검사하기 위해 우선 $10 \mu \mathrm{L}$ 의 전혈 을 $990 \mu \mathrm{L}$ 의 phosphate-buffered saline (PBS)와 혼합하여 희 석하였다. 희석된 전혈 $100 \mu \mathrm{L}$ 를 검사용 튜브에 분주하고 $5 \mu \mathrm{L}$ CD235a-fluorescein isothiocyanate 항체(Beckman Coulter, Fullerton, CA, USA) 및 $3 \mu \mathrm{L}$ CD59-phycoerythrin (PE) 항체 (Thermo Fisher Scientific)를 넣은 후 혼합하였다. 실온 암소에 서 20 분간 반응시킨 후 $500 \mu \mathrm{L} \mathrm{PBS}$ 를 가하고 5 분간 $1,500 \mathrm{~g}$ 에서 원심하여 세포를 세척하였으며 세척과정은 2차례 시행하였다.

세척된 원침액에 $1 \mathrm{~mL} \mathrm{PBS}$ 를 가하고 light scatter (forward scatter 및 side scatter [SSC])와 CD235a 발현을 이용하여 적혈 구를 gating하였다. 최소 500,000 개의 적혈구에서 CD59의 발현 정도를 분석하였으며, CD235a 양성 적혈구 중 PNH 클론(type II 또는 type III PNH 적혈구의 합)의 백분율을 측정하였다.

호중구에서 FLAER의 발현을 검사하기 위해 $100 \mu \mathrm{L}$ 의 전혈에 $5 \mu \mathrm{L}$ Alexa 488 labeled FLAER (Cedarlane, Burlington, ON, Canada), $10 \mu \mathrm{L}$ CD15-PE-Cyanine 5 (PC5) 항체(Beckman Coulter), $10 \mu \mathrm{L}$ CD24-PE 항체(Beckman Coulter), $10 \mu \mathrm{L}$ CD45-PE-Cyanine 7 (PC7) 항체(Beckman Coulter)를 가 하고 20 분간 실온 암소에서 반응시켰다. 이후 TQ Prep 장비 (Beckman Coulter)를 이용하여 적혈구 용혈을 시행하였다. 적 혈구 용혈 후 $1 \mathrm{~mL}$ 의 PBS를 가한 백혈구 부유액에서 SSC, CD45 및 $\mathrm{CD} 15$ 발현을 이용하여 $\mathrm{CD} 15$ 양성 호중구를 gating하였다. 최 소 50,000개의 CD15 양성 호중구에서 CD24 및 FLAER의 발현 정도를 분석하여 $\mathrm{PNH}$ 클론의 백분율을 측정하였다. 매 검사 시 음성 대조로 정상인의 검체를 함께 검사하였다.

\section{3. 채혈 후 시간 경과에 따른 표지자의 형광 강도 및 호중구의 세포 생존율}

적혈구 및 호중구에서 PNH 유세포 분석에 사용된 표지자의 형 광 강도가 72 시간 동안 실온 및 냉장 조건의 검체에서 변화하는 지 비교하기 위해 적혈구 및 호중구에서 사용된 표지자의 mean fluorescence intensity (MFI)를 측정하였다. 분석된 적혈구의 표 지자는 CD235a이며 호중의 표지자는 CD15였다. 또한 적혈구의 $\mathrm{PNH}$ 클론에서 CD59, 호중구의 PNH 클론에서 CD24, FLAER의 $\mathrm{MFI}$ 를 측정하였다.

실온 및 냉장보관한 4 종의 검체에 대해 72 시간 경과 시점에 7-aminoactinomycin D (7-AAD)를 이용하여 세포 생존율를 측 정하였다. 세포 생존율 분석을 위해 전혈 $100 \mu \mathrm{L}$ 에 7-AAD 시약 $20 \mu \mathrm{L}$ 를 넣고 잘 혼합한 후 실온에서 20 분간 반응시켰다. 이후 적 혈구 용혈을 시행하고 1차례 세척 후 1 시간 이내에 분석하였다. 호중구는 과립구의 대부분을 구성하는 점에 착안하여 먼저 SSC와 $\mathrm{CD} 45$ 분획으로 과립구 구역을 구분하고 과립구 중 7-AAD 발현이 낮은 과립구의 분율을 호중구의 생존율로 규정하였다.

\section{4. 통계 분석}

통계 분석은 MedCalc ver. 19.6 (MedCalc Software, Mariakerke, Belgium)을 이용하였으며, 자료는 중앙값(범 위)으로 나타내었다. 비교 검체 간 $\mathrm{PNH}$ 클론 백분율의 상관성 은 Pearson correlation analysis을 이용하여 분석하였으며, Bland-Altman plot으로 평균 차이 및 95\% 일치한계를 구하였 다. 연속변수의 비교는 $t$-test 및 Wilcoxon test를 이용하였으며, $P$ 값이 0.05 미만인 경우 통계학적으로 유의한 것으로 판정하였다.

\section{결과}

\section{1 검체의 PNH 클론}

당일 분석 $\mathrm{EDTA}$ 전혈 검체를 기준으로 환자군에서 $\mathrm{GPI}$ (glycosylphosphatidylinositol)-anchored protein의 발현이 감소된 비정상 $\mathrm{PNH}$ 클론의 중앙값(범위)은 적혈구에서 $56.05 \%$ (0.09\%-99.46\%), 호중구에서 89.70\% (0.14\%-99.71\%)였다. 환자군 중 14 명은 적혈구 및 호중구 모두에서 $1 \%$ 이상의 $\mathrm{PNH}$ 클 론을 가졌으나, 6 명은 적혈구 혹은 호중구(2명은 적혈구, 4 명은 호 중구) 중 하나에서만 $1 \%$ 이상의 PNH 클론이 검출되었다. 비환자 군에서 PNH 클론의 중앙값(범위)은 적혈구에서 $0.00 \%(0.00 \%-$ $0.70 \%)$, 호중구에서 $0.05 \%$ (0.03\%-0.32\%)로, 비환자군 중 3명 (20.0\%)만이 $0.1 \%$ 이상의 측정값을 보였으며 대부분은 $0.1 \%$ 미 만이었다.

\section{2. 당일 분석 EDTA 전혈 검체와 72시간 보관 전혈 검체 간 PNH 클론의 백분율 비교}

환자군 및 비환자군의 72 시간 동안 보관된 전혈 검체에서 적 혈구 및 호중구의 PNH 클론 백분율은 Table 1 과 같다. 환자군에 서 적혈구의 PNH 클론 백분율 중앙값은 실온보관 EDTA 전혈 검 체를 제외하고 모든 보관 검체에서 상승되는 경향성을, 호중구의 $\mathrm{PNH}$ 클론 백분율은 감소하는 경향성을 보였으나 유의한 차이를 나타내지 않았다. 그러나 실온보관된 EDTA 전혈 검체의 적혈구 및 호중구 중 PNH 클론 백분율 중앙값은 당일 분석결과보다 유의 하게 낮았다 $(P<0.001)$. 비환자군에서 $\mathrm{PNH}$ 클론의 백분율은 모든 

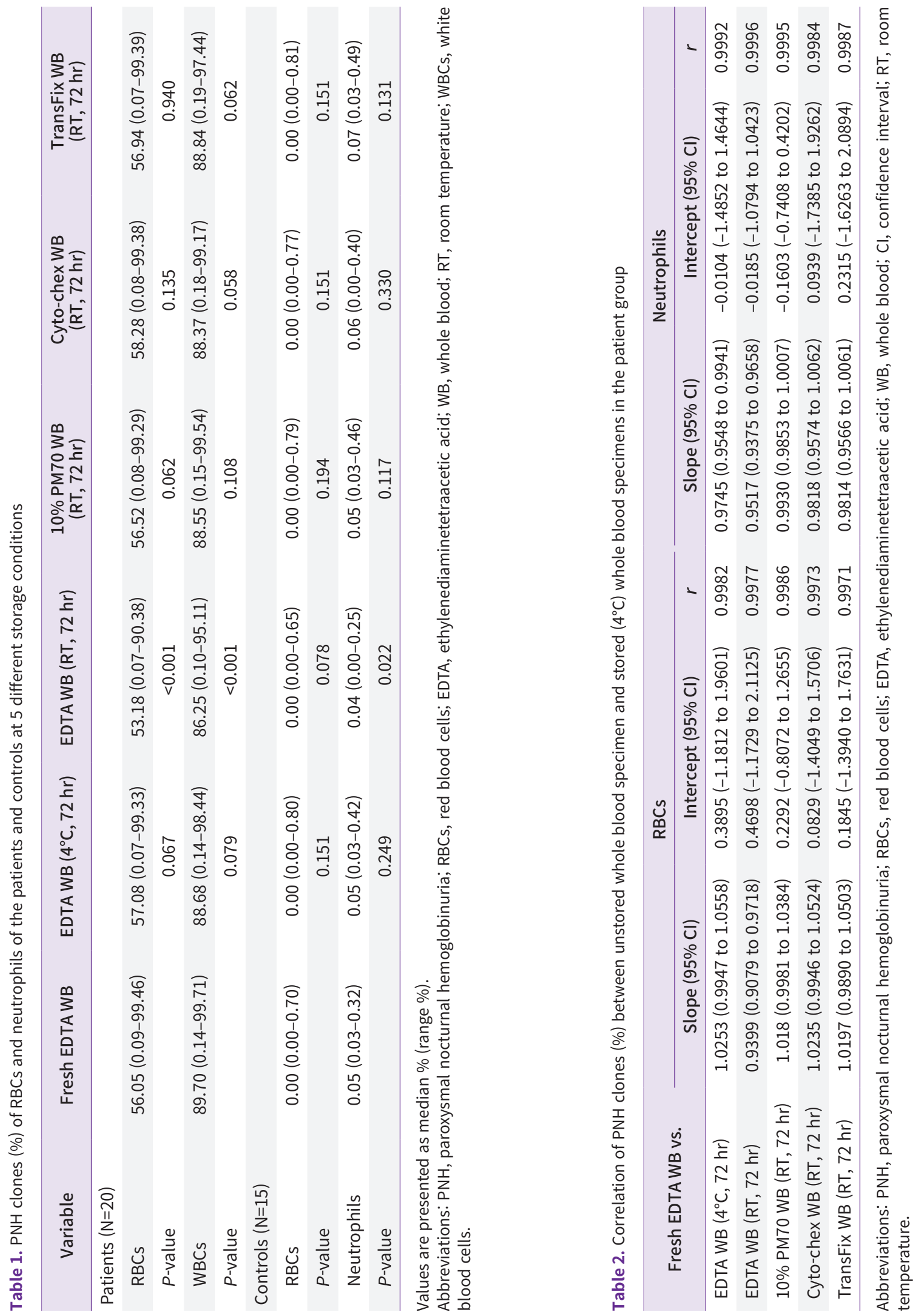
A

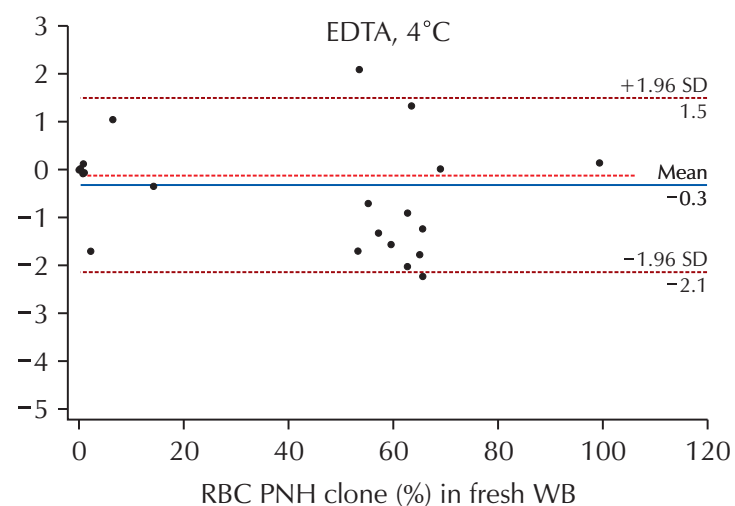

C

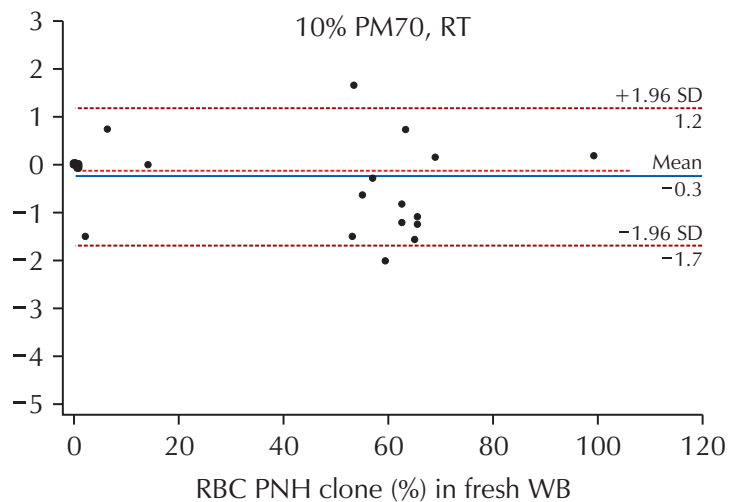

E

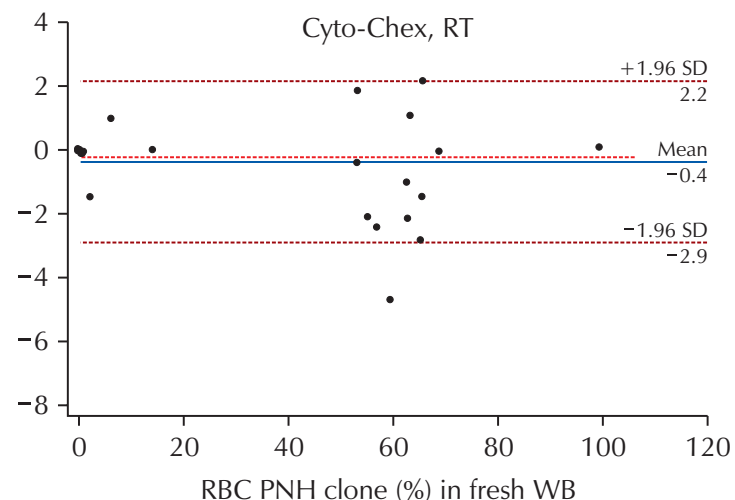

G

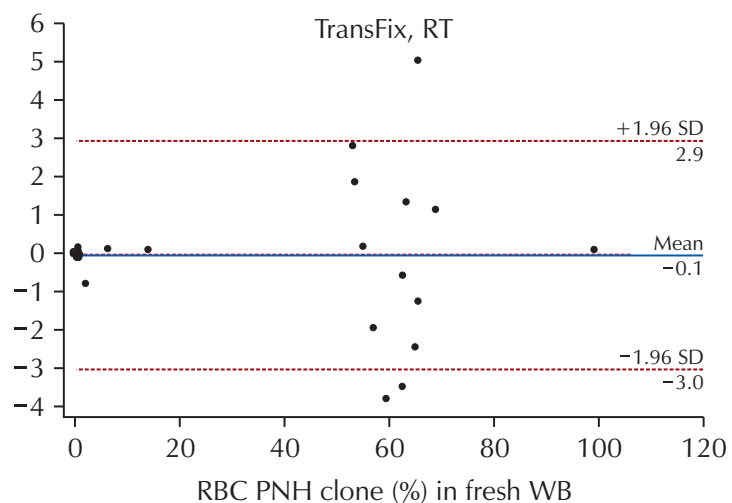

B

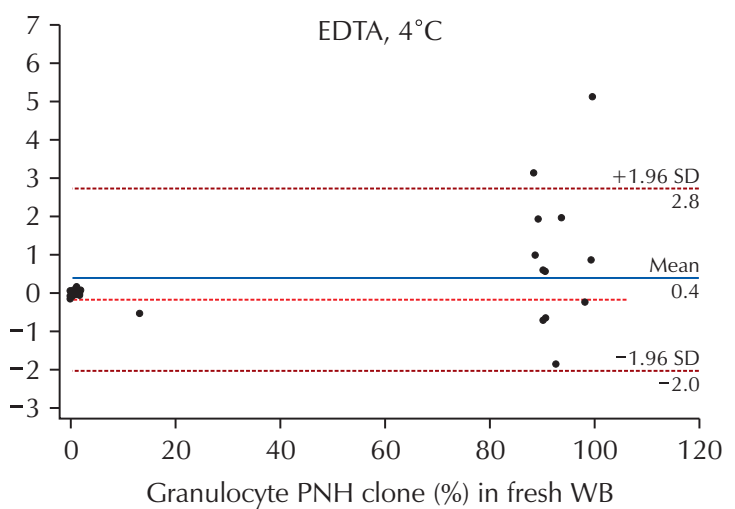

D

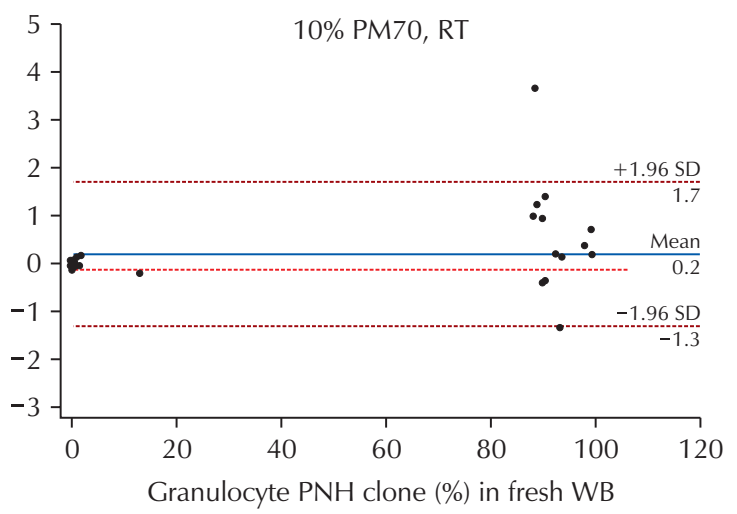

$\mathbf{F}$

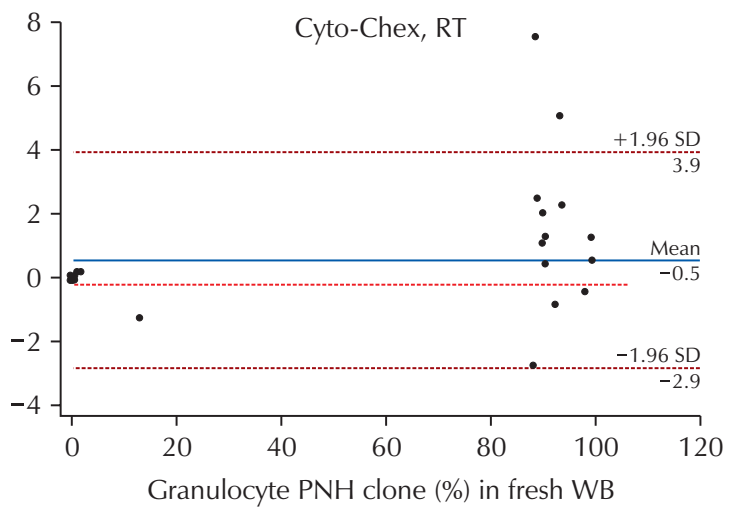

H

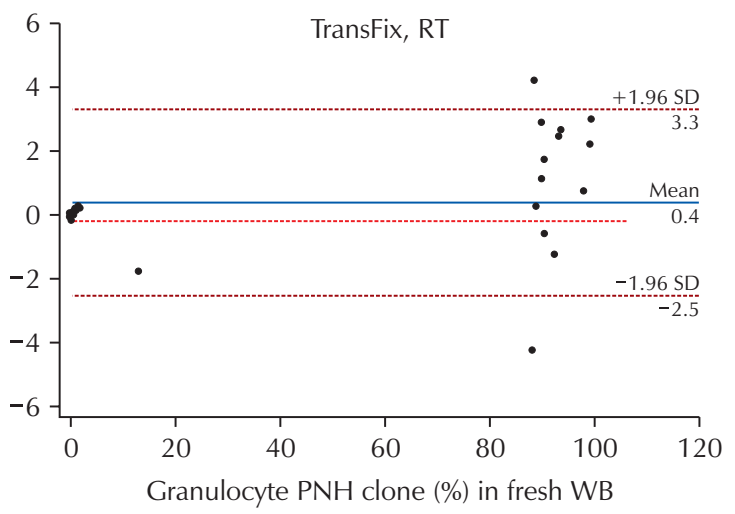

Fig. 1. (A-H) Comparison of paroxysmal nocturnal hemoglobinuria (PNH) clone (\%) in red blood cells (RBCs) and granulocytes between fresh specimen and $4^{\circ} \mathrm{C} /$ room temperature (RT) stored specimens. Abbreviations: WB, whole blood; SD, standard deviation. 
보관 검체에서 $1 \%$ 미만으로 안정되게 유지되었다.

환자군에서 당일 분석 EDTA 전혈 검체와 각 보관 전혈 검체 간 $\mathrm{PNH}$ 클론 백분율의 상관성을 비교한 결과, 적혈구 및 호중구 모 두에서 상관계수는 0.99 이상 $(P<0.001)$ 으로 우수한 상관성을 보 였다(Table 2).

당일 분석 검체에 대한 각 보관 검체별 적혈구 $\mathrm{PNH}$ 클론 백 분율의 평균 차이(95\% 일치한계)는 냉장보관 EDTA 검체 -0.8 (-4.1 to 2.5$)$, 실온보관 $10 \% \mathrm{PM} 70$ 검체 -0.8 (-3.7 to 2.2$)$, 실
온보관 Cyto-Chex 검체 -0.9 (-4.8 to 3.0), 실온보관 TransFix 검체 -0.6 (-4.3 to 3.1)으로 음의 차이를 나타냈으나 유의한 계통 적 차이는 없었다.

당일 분석 검체에 대한 각 보관 검체별 호중구 $\mathrm{PNH}$ 클론 백분 율의 평균 차이(95\% 일치한계)는 냉장보관 EDTA 검체 0.9 (-2.6 to 4.3$)$, 실온보관 $10 \% \mathrm{PM} 70$ 검체 0.7 (-1.9 to 3.4$)$, 실온보관 Cyto-Chex 검체 0.6 (-3.4 to 4.7), 실온보관 TransFix 검체 0.5 (-3.1 to 4.1)로 양의 차이를 나타냈으나 유의한 계통적 차이는
A

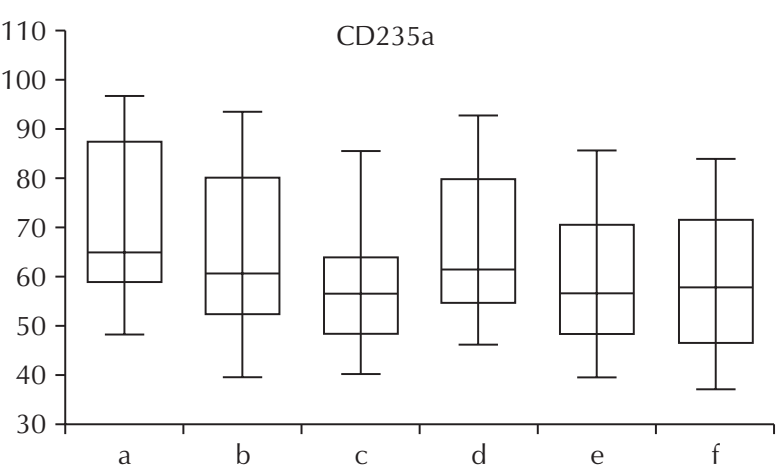

C

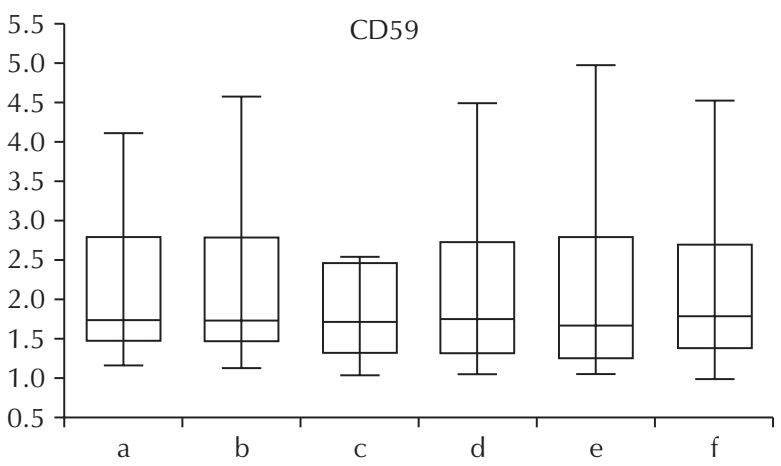

E

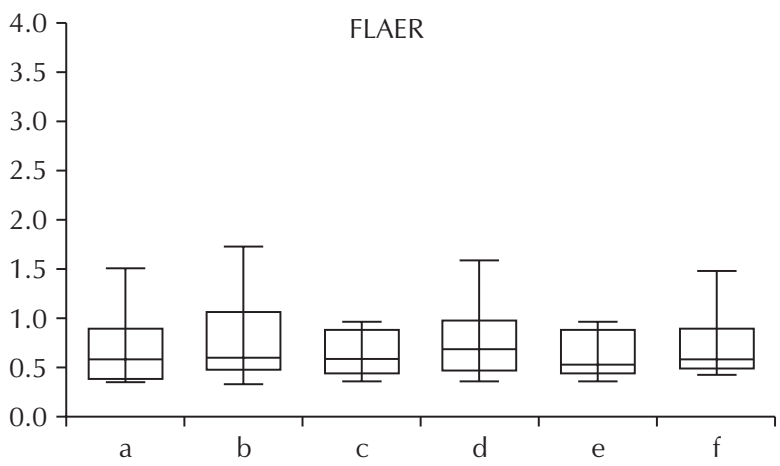

B

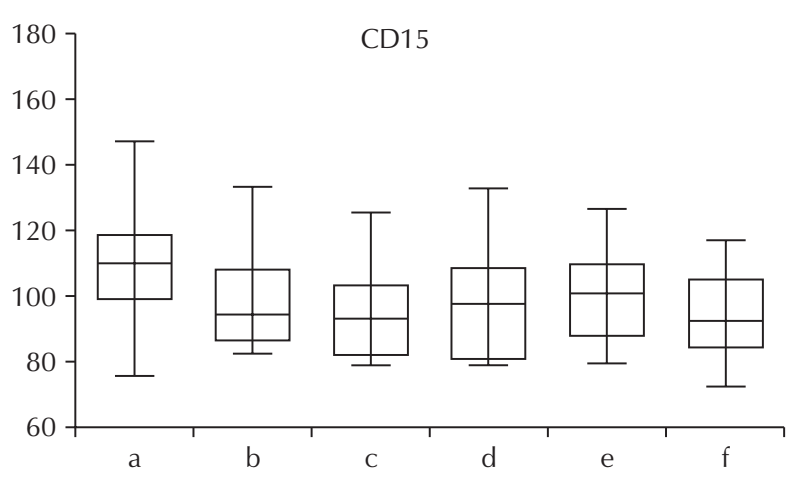

D

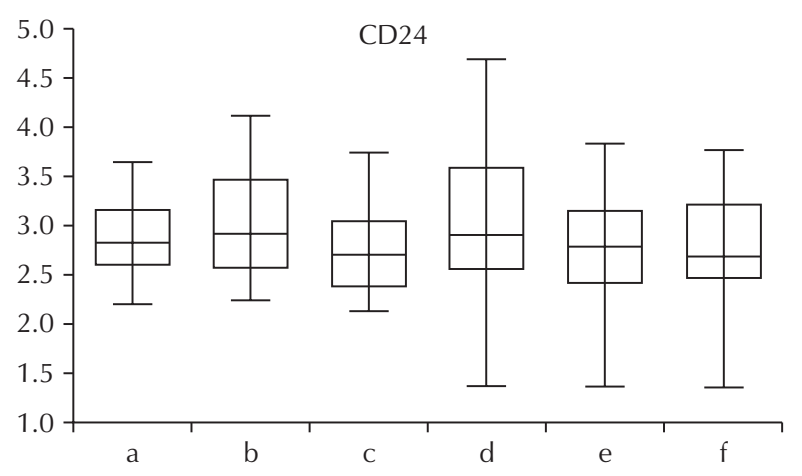

Fig. 2. (A-E) Comparison of mean fluorescence intensity (MFI) of cell surface markers (CD235a, CD15, CD59, CD24, and FLAER) among fresh (a) and $4^{\circ} \mathrm{C} /$ room temperature (RT) stored whole blood (WB) specimens (b: ethylenediaminetetraacetic acid [EDTA] WB in $4^{\circ} \mathrm{C}$; $\mathrm{C}$ : EDTA WB in RT; d: 10\% PM70 WB in RT; e: Cyto-Chex WB in RT; f: TransFix WB in RT). In a box-and-whisker plot, the central box represents the values from the lower to upper quartile ( 25 to 75 percentile). The middle line represents the median. A line extends from the minimum to the maximum value. 
없었다. 적혈구 및 호중구에서 PNH 클론 백분율의 최대 차이는 $1 \%-20 \%$ 이하 백분율 구간에서 \pm 2 이내, $20 \%$ 초과 백분율 구 간에서 $10 \%$ 이내였다(Fig. 1).

\section{3. 환자군의 적혈구에서 PNH 클론의 CD59 발현 강도}

당일 분석 검체에서 적혈구에 발현되는 CD235a의 MFI는 64.6 (47.9-96.3)이었으나, 실온보관 EDTA 검체의 MFI는 56.1 (39.5$85.3)$ 로 유의하게 감소되었다 $(P<0.001)$. 냉장보관 EDTA 검체 및 실온보관 $10 \% \mathrm{PM} 70$ 검체의 MFI도 각각 60.35 (39.0-93.3), 60.95 (45.5-92.3)로 유의하게 낮았다 $(P<0.001)$. 또한 실온보 관 Cyto-Chex 검체 및 TransFix 검체의 MFI도 각각 56.1 (39.085.3), 57.2 (36.7-83.5)로 유의하게 낮았다 $(P<0.001, P<0.001)$.

적혈구 중 PNH 클론에 속하는 세포에서 발현되는 CD59 형광 의 MFI는 당일 분석 검체에서 1.70 (1.13-5.08)이었으며, 실온 및 냉장보관 EDTA 검체, 실온보관 $10 \% \mathrm{PM} 70$ 검체의 MFI는 각각 1.68 (1.00-4.69), 1.69 (1.09-4.91), 1.71 (1.01-4.95)로 유의한 차이는 없었다. 또한 실온보관 Cyto-Chex 검체 및 TransFix 검체 의 MFI도 각각 1.63 (1.02-4.95), 1.76 (0.94-5.01)으로 유의한 차이를 나타내지 않았다(Fig. 2).

\section{4. 환자군의 호중구에서 PNH 클론의 CD24 및 FLAER 발현 강도}

당일 분석 검체에서 호중구에 발현되는 CD15의 MFI는 109.5 (75.2-147.0)였으나 실온보관 EDTA 검체의 MFI는 93.0 (79.2$125.1)$ 으로 유의하게 낮았다 $(P<0.001)$. 또한 냉장보관 EDTA 검 체, 실온보관 $10 \% \mathrm{PM} 70$ 검체, 실온보관 Cyto-Chex 검체, 실 온보관 TransFix 검체의 MFI도 각각 94.5 (82.4-133.1), 97.7 (79.0-155.1), 97.9 (76.5-126.1), 94.5 (72.2-169.1)로 유의한 차이를 나타냈다 $(P=0.004, P=0.012, P=0.001, P=0.001)$.

호중구 중 $\mathrm{PNH}$ 클론에 속하는 세포에서 발현되는 $\mathrm{CD} 24$ 및 FLAER의 MFI는 당일 분석 검체에서 각각 2.80 (1.26-4.04), 0.57 (0.34-2.76)이었다. 실온보관 EDTA 검체는 CD24의 MFI가 2.68 (1.23-3.72), 0.5 (0.3-2.6)로 중앙값은 낮으나 유의한 차이는 없 었으며( $P=0.07), \mathrm{FLAER}$ 의 MFI는 0.56 (0.33-3.63)으로 차이가 없었다. 냉장보관 EDTA 검체, 실온보관 $10 \% \mathrm{PM} 70$ 검체, 실온보 관 Cyto-Chex 검체, 실온보관 TransFix 검체에서 CD24의 MFI 는 각각 2.89 (1.18-4.11), 2.88 (1.33-4.68), 2.76 (1.33-3.82), 2.71 (1.43-3.86)로 당일 검체와 보관 검체 간에 유의한 차이 는 없었다. 또한 FLAER의 MFI도 각각 0.58 (0.30-2.63), 0.66 (0.34-2.62), 0.52 (0.33-3.63), 0.56 (0.41-2.70)으로 당일 검체 와 보관 검체 간에 유의한 차이를 나타내지 않았다(Fig. 2).

\section{5. $\mathrm{CD} 15$ 양성 호중구의 분율}

당일 검체에서 유핵세포 중 CD15 양성 호중구의 분율은 $38.6 \% \pm$ $14.8 \%$ 이었다. 72 시간 보관 시점의 냉장보관 EDTA 전혈 검체에 서 $\mathrm{CD} 15$ 양성 호중구의 분율은 $39.3 \% \pm 14.9 \%$ 로 당일 검체와 비교하여 유의한 차이를 나타내지 않았으며, 72 시간 보관 시점의 실온보관 $10 \%$ PM70 전혈, Cyto-Chex 전혈, TransFix 전혈 검체 에서 $\mathrm{CD} 15$ 양성 호중구의 분율도 각각 $38.6 \% \pm 14.8 \%, 39.4 \% \pm$ $14.6 \%, 39.0 \% \pm 14.6 \%$ 로 차이를 나타내지 않았다.

\section{6. 호중구의 세포 생존도}

72시간 보관 시점의 냉장보관 EDTA 전혈 검체에서 SSC/CD45 gating으로 구분된 호중구 세포의 생존율은 95.8\% (92.0\%98.3\%)로 양호한 생존율을 유지하였으나, 실온보관 검체에서 호 중구 세포의 생존도는 10\% PM70 전혈 15.7\% (9.8\%-21.7\%), Cyto-Chex 전혈 8.1\% (4.4\%-9.3\%), TransFix 전혈 8.3\% (5.2\%-10.2\%)로 냉장보관 EDTA 전혈 검체와 비교하여 유의하 게 낮았다 $(P<0.001)$.

\section{고찰}

$\mathrm{PNH}$ 의 진단 및 추적관찰 시 검사법으로 시행되는 유세포 분석 법과 관련된 주요 한계점은 검체의 보관 및 운반과정이 지연될 경 우 유발될 수 있는 세포표지자의 불안정성이다. 림프구 아형 분석 의 경우 미국질병관리예방센터는 EDTA 및 헤파린 전혈 검체에 대 한 검사를 72 시간 내 시행하도록 가이드라인으로 제시한다[10]. 그러나 백혈구는 시간이 경과하면 scatter와 항원 표현이 변화할 수 있으므로 채취 후 48시간 이상 경과된 검체가 유세포 분석 검 사에 적절한지에 대한 의문은 지속적으로 제기되어 왔으며, 이를 보완하기 위해 특수 채혈관을 이용한 전혈 고정법이 소개되었다.

상품화된 특수 채혈관은 Cyto-Chex 및 TransFix 채혈관이 가장 대표적이며 특수 채혈관의 전혈 검체는 림프구의 scatter signal 및 세포표지자의 발현 정도를 7-10일까지 안정되게 유지 하였다 $[5,11]$. 반면, 과립구는 림프구와 달리 시간 경과에 따라 $\mathrm{SSC}$ 값의 감소가 관찰되었으며, 세포막의 투과도 증가로 형태학 적 변화가 나타났다. 그러나 TransFix 전혈 검체에서 CD45 발현 을 이용하면 과립구의 적절한 검출은 가능하였고, 이는 과립구 세 포의 형태학적 변화가 세포표지자의 발현에 미치는 영향이 크지 않음을 반영하였다[11]. 또한 Cyto-Chex 전혈 검체도 세포표지자 의 발현이 비교적 안정되게 유지됨이 보고되었다[12].

이와 같이 세포를 고정하는 상품화된 특수 채혈관은 세포표지 자를 분석하는 유세포 분석에서 장점이 있지만 현재 유세포 분석 법을 수행하는 국내의 많은 임상검사실의 경우 검사 건수 및 채 
혈관의 비용 등을 고려할 때 특수 채혈관 도입은 용이하지 않다. 본 연구에서는 TransFix나 Cyto-Chex 등의 물질 대신 질량이 작 은 Ficoll 중합체 PM70을 첨가하여 세포를 고정하는 방법이 세포 의 구분 및 표지자 발현의 유지에 적합한지 평가하였으며, $10 \%$ PM70 중합체를 이용한 방법이 특수 채혈관과 유사한 세포 고정 효과를 나타냄을 입증하였다.

본 연구에서는 낮은 PNH 클론 백분율(0.1\%-1.0\%)을 나타낸 검체의 수가 매우 적어 $1.0 \%$ 이상의 $\mathrm{PNH}$ 클론을 나타낸 검체만 을 대상으로 보관조건별 PNH 클론 백분율의 변화를 비교하였다. 전혈 검체의 PNH 클론 백분율은 실온보관 EDTA 전혈 검체 외의 다른 보관 검체에서 당일 검체에 비해 중앙값이 적혈구 수에서는 증가하고 호중구에서는 감소하는 경향성을 보였으나 차이가 유 의하지 않았으며 검체별 차이가 절대값 기준으로 2 미만이거나 $10 \%$ 미만이었다. 그러나 실온보관한 EDTA 전혈 검체의 경우 백 분율이 적혈구 및 호중구 모두에서 감소하였으며 그 차이가 유의 하였다. 실온보관된 EDTA 전혈 검체는 PNH 클론 분석에서 부적 합하였으나, 냉장보관할 경우 EDTA 전혈 검체는 72 시간 내에서 $\mathrm{PNH}$ 클론의 안정적 분석이 적혈구뿐만 아니라 호중구에서도 가 능하였다. 이전의 한 국내 연구는 적혈구는 실온보관해도 7 일까 지 분석이 안정하다고 보고하였으나[3], 본 연구에서는 실온보관 은 호중구뿐 아니라 적혈구에서도 $\mathrm{PNH}$ 클론의 백분율을 낮추어 $\mathrm{PNH}$ 클론 분석 시 EDTA 전혈 검체는 냉장보관하는 것이 추천되 었다.

이전 연구에서 호중구의 PNH 클론의 크기는 대상 검체가 2개 로 적었지만 냉장보관하면 72 시간까지 안정되게 측정된다고 보고 하였는데[3], 20명의 환자 검체를 평가한 본 연구에서도 같은 결 과를 얻어 $\mathrm{PNH}$ 분석 가능 조건은 냉장보관, 72 시간까지로 적용할 수 있다고 판단하였다. 실온보관 조건에서는 $10 \%$ PM70 중합체 및 특수 채혈관을 이용한 세포고정법을 적용한 검체가 PNH 분석 에 적절하였으며 $10 \%$ PM70 중합체 이용이 특수 채혈관의 대안 이 될 수 있었다.

세포고정법은 유세포 분석에서 임상 검체를 안정화하는 방법 으로 제안되어 왔으며, NEQAS 같은 외부정도관리 프로그램에서 적용되어 왔다[13,14]. 그러나 이전 연구에서 세포고정법은 세포 표지자의 MFI를 낮춘다고 보고되었으며 특수 채혈관 검체에서도 일부 백혈구 세포표지자의 MFI는 시간 경과에 따라 감소되었다 $[4,15,16]$. 본 연구에서도 $10 \%$ PM70 중합체를 첨가한 전혈이나 특수 채혈관의 전혈 검체에서 호중구 표지자인 CD15의 MFI는 시 간 경과에 따라 감소하여 EDTA 전혈 검체와 유사하였다. 또한 적 혈구 표지자인 CD235a의 MFI도 세포고정법이 적용되더라도 보 관 검체에서 감소하였다.

반면, PNH 클론에서 CD59, CD24, FLAER의 MFI는 당일 검체
에 비교해 유의한 차이가 없었는데, 이는 관련 표지자의 발현이 감 소된 PNH 클론에서는 MFI 감소의 영향이 결과에 크게 반영되지 않는다고 추측하였다. 그러나 상대적으로 높은 MFI로 발현되는 표 지자의 경우 특수 채혈관을 사용하더라도 MFI의 감소는 예방할 수 없다고 생각하였다.

비록 보관 검체에서 호중구의 CD15 발현 강도가 유의한 감소 를 보였으나 발현의 감소가 림프구나 단구와 중첩되는 수준은 아 니었고 백혈구 중 호중구의 분율은 유의한 변화를 나타내지 않아 충분한 세포를 획득하여 호중구의 PNH 클론을 분석할 수 있었다. 이는 보관 검체에서 특정 세포군의 분율이나 세포 수가 일정 기간 유지되었다는 이전 연구결과와 일치하는 것이었다[11,12]. 호중 구 세포의 생존율은 $10 \% \mathrm{PM} 70$ 전혈 검체가 특수 채혈관 전혈 검 체에 비해 높았지만, 세포고정법을 적용한 검체 모두가 냉장보관 EDTA 전혈에 비해 유의하게 낮아 불량한 세포 생존율을 보였다. 세포고정법을 적용한 검체는 실온보관하더라도 세포 분획과 표지 자의 발현 유지를 통해 유세포 분석은 가능하지만 세포의 막 투과 성 증가와 변성을 막는 데 한계가 있었다. 비록 $10 \%$ PM70 전혈 검체가 호중구의 세포막 손상을 줄이는 것으로 보고되었지만[6], 본 연구에서는 저분자량 Ficoll 중합체 PM70을 이용한 세포 생존 율의 개선효과가 냉장보관에 비해 불량하여 냉장보관 조건이 호중 구의 세포 생존율을 유지하는 데 최적임을 알 수 있었다.

결론적으로, $\mathrm{PNH}$ 유세포 분석이 지연되는 경우 전혈 검체 를 냉장보관하면 72 시간까지 $\mathrm{PNH}$ 클론의 안정적인 정량분석 이 가능하였다. 실온보관 조건에서 $10 \% \mathrm{PM} 70$ 를 포함한 검체는 TransFix나 Cyto-Chex 채혈관의 대안이 될 수 있었다. PNH 클론 에서 감소되는 세포표지자의 형광 발현의 강도와 호중구의 분율은 모든 보관 조건에서 유지되었다. 호중구의 세포 생존도는 냉장보 관 조건에서만 양호하였다.

\section{감사의 글}

본 연구는 2019년 대한임상검사정도관리협회의 연구비 지원을 받아 수행되었다.

\section{ORCID}

Sewon Yoon https://orcid.org/0000-0001-6091-3395

Jimyung Kim https://orcid.org/0000-0003-0530-3425

Seon Young Kim https://orcid.org/0000-0001-5459-9635

Jinsook Lim https://orcid.org/0000-0003-2814-3284

Gye Cheol Kwon https://orcid.org/0000-0002-4886-0590

Sun Hoe Koo https://orcid.org/0000-0003-3715-7151 


\section{REFERENCES}

1. Devalet B, Mullier F, Chatelain B, Dogne JM, Chatelain C. Pathophysiology, diagnosis, and treatment of paroxysmal nocturnal hemoglobinuria: a review. Eur J Haematol 2015;95:190-8.

2. Borowitz MJ, Craig FE, Digiuseppe JA, Illingworth AJ, Rosse W, Sutherland DR, et al. Guidelines for the diagnosis and monitoring of paroxysmal nocturnal hemoglobinuria and related disorders by flow cytometry. Cytometry B Clin Cytom 2010;78:211-30.

3. Lee SH, Bang HI, Shin YJ, Shin WY, Kim J, Park R, et al. Evaluation of time and temperature stability of paroxysmal nocturnal hemoglobinuria cells by flow cytometry. Lab Med Online 2019;9:57-62.

4. Diks AM, Bonroy C, Teodosio C, Groenland RJ, de Mooij B, de Maertelaere E, et al. Impact of blood storage and sample handling on quality of high dimensional flow cytometric data in multicenter clinical research. J Immunol Methods 2019;475:112616.

5. Warrino DE, DeGennaro LJ, Hanson M, Swindells S, Pirruccello SJ, Ryan WL. Stabilization of white blood cells and immunologic markers for extended analysis using flow cytometry. J Immunol Methods 2005;305:107-19.

6. Wong KH, Sandlin RD, Carey TR, Miller KL, Shank AT, Oklu R, et al. The role of physical stabilization in whole blood preservation. Sci Rep 2016;6:21023.

7. Toth K, Wenby RB, Meiselman HJ. Inhibition of polymer-induced red blood cell aggregation by poloxamer 188 . Biorheology 2000;37:301-12.

8. Pamphilon D, Selogie E, McKenna D, Cancelas-Peres JA, Szczepiorkowski ZM, Sacher R, et al. Current practices and prospects for standardization of the hematopoietic colony-forming unit assay: a report by the cellular therapy team of the Biomedical Excellence for Safer Transfusion (BEST) Collaborative. Cytotherapy 2013;15:255-62.

9. Sutherland DR, Illingworth A, Marinov I, Ortiz F, Andreasen J, Payne D, et al. ICCS/ESCCA consensus guidelines to detect GPI-deficient cells in paroxysmal nocturnal hemoglobinuria (PNH) and related disorders part 2 - reagent selection and assay optimization for high-sensitivity testing. Cytometry B Clin Cytom 2018;94:23-48.

10. Mandy FF, Nicholson JK, MCDougal JS; CDC. Guidelines for performing single-platform absolute CD4+ T-cell determinations with CD45 gating for persons infected with human immunodeficiency virus. Centers for Disease Control and Prevention. MMWR Recomm Rep 2003;52(RR-2):1-13.

11. Canonico B, Zamai L, Burattini S, Granger V, Mannello F, Gobbi P, et al. Evaluation of leukocyte stabilization in TransFix-treated blood samples by flow cytometry and transmission electron microscopy. J Immunol Methods 2004; 295:67-78.

12. Davis C, Wu X, Li W, Fan H, Reddy M. Stability of immunophenotypic markers in fixed peripheral blood for extended analysis using flow cytometry. J Immunol Methods 2011;363:158-65.

13. Jani V, Janossy G, Iqbal A, Mhalu FS, Lyamuya EF, Biberfeld G, et al. Affordable CD4+ T cell counts by flow cytometry. II. The use of fixed whole blood in resource-poor settings. J Immunol Methods 2001;257:145-54.

14. Reilly JT, Barnett D. UK NEQAS for leucocyte immunophenotyping: the first 10 years. J Clin Pathol 2001;54:508-11.

15. McCarthy DA, Macey MG, Cahill MR, Newland AC. Effect of fixation on quantification of the expression of leucocyte function-associated surface antigens. Cytometry 1994;17:39-49.

16. Schumacher A. Effect of ex vivo storage and Cyto-Chex on the expression of P-selectin glycoprotein ligand-1 (PSGL-1) on human peripheral leukocytes. J Immunol Methods 2007;323:24-30. 